\title{
Reply to the Letter by E. Czerwinski Regarding "The Utility and Limitations of FRAX: A US Perspective"
}

\author{
Stuart L. Silverman • Andrew D. Calderon
}

Published online: 17 January 2012

(C) Springer Science+Business Media, LLC 2012

To the Editor:

Professor Czerwinski corrects our misstatement that FRAX is available in Poland as a CD when it is in fact available as a handheld calculator. We laud the continued increase in availability of FRAX, now in 18 languages including Polish. FRAX is available on the Web, as a desktop application, as an iPhone application, and now as a hand-held calculator. We will follow with interest the validation of the calculator against online FRAX and possible use in countries with poor or no Internet access.

Thank you,

Stuart L. Silverman, MD FACP FACR

Andrew D. Calderon

S. L. Silverman $(\square)$

Cedars-Sinai Medical Center,

Los Angeles, CA, USA

e-mail: stuarts@omcresearch.org

S. L. Silverman · A. D. Calderon

The OMC Clinical Research Center,

Beverly Hills, CA, USA 